\title{
THE WITHDRAWAL FROM SERVICE OF PUBLIC UTILITY COMPANIES
}

\author{
OLTVER P. FIELD
}

The withdrawal from service by a public utility is a problem of comparatively recent origin. The greater part of the nineteenth century witnessed a rather unseemly scramble for entry into the field of public service on the part of many individuals and companies. The entry into the field of public service business was for some years before and after the Civil Wrar commonly associated with the grant of certain favors by the local, state, or national governments. The records of state legislatures contain many sordid tales of the various means and influences which were brought to bear upon the lawmakers, not without some measure of success, to obtain these favors which were so generously handed out by the legislative authorities. What the legislatures had done, the courts insured against being undone by the formulation, of the doctrine that a corporate charter was a contract which could not be impaired by state action.

It was not long until state constitutions began to show the effect of this rush for legislative favors, for with the revision of the constitutions of many states during the middle period of the century, provisions were inserted shackling the hands of the legislative bodies in the matter of franchise grants. These provisions were aimed particularly to prevent the future legislatures from bestowing similar favors upon public service companies.

In those beginning days of modern public service in this country, the only method of enforcing the peculiar obligations which were said to rest upon these callings was by way of the courts. Sometimes citizens would seek to obtain court action to force the utility owners to serve them; at other times they would sue for damages in tort; and in still other instances they would sue in contract. At times the legal representative of the local or state government would attempt to enforce the duties which were thought to be owing to the community by the utility owners. It is not surprising, therefore, to find that these same methods were utilized to prevent utilities from discontinuing their service and withdrawing from the field of public callings. So we find some of the early cases on discontinuance initiated by citizens seeking in their private capacity to prevent the withdrawal. ${ }^{2}$ In others

I See, for example, the bill filed by ten citizens in Brouncll v. Old Colony Railroad (1895) 164 Iiass. 29, 41 N. E. 107. In the following cases single individuals sought court aid, Savannah Canal Co. v. Shuman (1893) 91 Ga. 400, 17 S. E. 937; People ex rel. Van Dylee v. Colorado Cent. $R y$. (1890, C. C. D. Colo.) 42 Fed. 638. 
the action was instituted by legal representatives of the politically organized group, ${ }^{2}$ and, in the earliest case, by the legal representative of the state, who was seeking to punish the utility owners for their failure to continue service by subjecting them to criminal prosecution. ${ }^{3}$

The courts did not prove to be an altogether effective agency for the supervision of the utilities; and great injustices and discriminations seem to have been perpetrated in the matter of rates and services. Competition would sometimes operate as a safeguard to the public, but at other times not only failed to act as a buffer against the utility companies, but resulted in actual hardship to the public. It was not long, therefore, before other means of enforcing the duties fastened upon public utilities were devised. As the result of considerable experimentation, the modern public utility commission has come to be the agency chosen by most of the states for regulating the utilities. To these regulatory commissions has been given also the power to control the withdrawal of 'public utilities from service, ${ }^{4}$ although the instrumentality of the courts has not been wholly abandoned. ${ }^{\circ}$

Some doubts were expressed by the courts in the earlier cases as to the power of the utility owners to discontinue service in toto even if the service was a losing one. And it was, of course.

2 As illustrative, see People v. Albany \& Vt. R. R. (1862) 24 N. Y. 261; Attormey Gen. v. The West Wis. Ry. (1874) 36 Wis. 466.

${ }^{3}$ Carter v. Commonwealth (1823) 2 Va. Cas. 354. The court held in this case that the statute in question did not make it a crime to fail to oporate the ferry which was involved, but held that such failure to operate was merely grounds for forfeiture of the charter.

4 See Va. Sts. 1923, sec. 3810, and Ohio Code, 1920, sec. 504-3. Statutory provisions giving the commission general control over facilities and oporntion are construed to include withdrawal and abandonment. Peoplo ex rol. Hubbard v. Colorado Title \& Trust Co. (1918) 65 Colo. 472, 178 Pac. 6; Herpolsheimer Co. v. Lincoln Traction Co. (1914) 96 Neb. 154, 147 N. W. 206. The Interstate Commerce Commission has been given power to permit the withdrawal of interstate carriers in sec. 402, pars. 18-20 of the Transportation Act of 1920 .

- In Iowa, petitions for permission to withdraw must be filed with the courts, and they pass upon these petitions. See Iowa Code, 1897, sec. 2092. Also State ex rel. Brown v. Beaton (1920) 190 Iowa, 223, 178 N. W. 1; State of Iowa v. Old Colony Trust Co. of Boston (1914, C. C. A. 8th) 215 Fed. 307. The courts are still resorted to when commission findings are assailed on questions of law. As a recent example of resort to the courts by the state for immediate action see the case of McCran v. Publio Scrvico $R y$. (1923) 95 N. J. Eq. 22, 122 Atl. 205, where the owners of the utility had discontinued service because of a strike. The court held that mandamus would issue to compel the owners to operate the car lines, that the owners would go bankrupt just as quickly by letting the plant lie idle as thoy would by operating it, and that, if necessary, the court would appoint a receiver to operate the road. This case illustrates the lengths to which a court can go, if it is so disposed, in aiding the public in compelling the utility owners to fulfill the duties which rest upon them. 
in the case where the utility was not paying, that the owners -wished to withdraw from the business. An early federal case contains this dictum: ${ }^{6}$

"That a railroad cannot be abandoned after it has become one of the thoroughfares of the country, and that the company will, by proceedings in behalf of the state, be forced to continue the road and perform all its duties to the public is beyond question."

A few years later a state court made a very forceful statement to the same effect, answering the argument that the corporation could abandon the utility enterprise against the will of the state by saying,?

"The possible effects of such a claimed power are utter disaster to the great interests of the state, certain destruction of private property, in which whole communities, created and existing upou the faith of the continuous use of the chartered powers, are interested, and, indeed, the life of the citizen, as well as his property rights, are thus jeopardized. Upon principle it would seem plain that railroad property, once devoted and essential to public use, must remain pledged to that use, so as to carry to full completion the purpose of its creation; and that this public right, existing by reason of the public exigency, demanded by the occasion, and created by the exercise by a private person of the powers of the state, is superior to the property rights of corporations, stockholders, and bondholders."

It will be noticed that these early dicta treat the question as one involving a balancing of economic and social interests. Primary emphasis is placed upon the consequences of a proposed discontinuance of service. There is scarcely discernible any suggestion that a duty to continue operation arose from any charter contract.

Whatever may have been the doubts expressed in these earlier cases, it seems that the modern rule is that a state may not compel the owners of a utility to continue operation if the utility is losing money on its entire service with no reasonable prospect of earning in the near future a fair return on the money invested." The same rule obtains if the source of supply upon which the utility depends becomes exhausted. ${ }^{\circ}$ In either of the above cases the owners may totally abandon the service, although they must satisfy the proper governmental agency that they are within the

\footnotetext{
'Talcatt v. Pine Grove Township (1872, C. C. E. D. Mich.) 1 Flipp. 120, 145.

7 Gates v. Boston \& N. Y. Air-Linze R. R. (18s5) 53 Conn. 338, 343, 5 Atl. 695, 699. For a review of the early cases see Chaplin, Limitation upon the Right of Withdravsal from Public Employment (1903) 16 H.Mv. L. REv. 555.

8 Brooks-Scanlon Co. v. Railroad Comm. of La. (1920) 251 U. S. 396, 40 Sup. Ct. 183; Bullock v. Railroad Comm. of Fla. (1920) 254 U. S. 513, 41 Sup. Ct. 536; Railroad Comm. of Teras v. Eastern Texas R. R. (1923) 204 U. S. 79, 44 Sup. Ct. 247. For note on earlier cases see L. R. A. 1915 A 546. ${ }^{3}$ Fellows v. Los Angeles (1907) 151 Calif. 52, 90 Pac. 137; Village of St. Clairsville v. Public Util. Comm. (1921) 102 Ohio St. 574, 132 N. E. 151.
} 
class of losing utilities to which this rule applies. For the state to compel the owners of a utility to operate it after it has been. shown that continued service can only be rendered at a loss is said to deprive them of their property without "due process of law" and to take from them their property without just compensation. ${ }^{10}$

The technique which the courts have used in these withdrawal cases has been largely that of contract. It so happened that from the nature of the business involved many of the owners of public utilities were corporations, chartered by the state. From the time of the Dartmouth College case ${ }^{11}$ these corporate charters have been regarded as contracts which might not be impaired by state action. The result of this doctrine was that the privileges which had been granted to public service companies by the legislatures could not be snatched from the corporations by succeeding and more virtuous ones. To phrase it in terms of the public utility problem here under consideration, the doctrine that a charter was a contract resulted in allowing the corporations to stay in the public service field, unmolested by legislative intervention so far as their franchise privileges were concerned. Subsequent de. cisions, however, have badly mutilated the doctrine enunciated in the Dartmouth College case. ${ }^{12}$

The courts still pay homage, however, to the doctrine of the charter contract; and it is from this source that we get the first fundamental proposition in the process of reasoning which is found in withdrawal cases. It is that the utility owner is bound to operate the utility for the period of the charter if he is expressly required to do so, despite the fact that he may be losing money by the continued operation of the plant. ${ }^{13}$ The next following proposition is that the acceptance by a corporation of a charter for a term of years does not obligate the grantee to construct the plant, nor does the fact that the utility plant is constructed by virtue of the authority given in the charter, and service rendered to the public by such plant, obligate the owner to operate the

10 See cases cited supra, note 8. Additional cases involving total abandonment enunciate and apply the same rule. Jack v. Williams (1902, C. C. D. S. C.) 113 Fed. 823; N. Y. Trust Co. v. Portsmouth \& Exeter Streot Ry. (1911, G. C. D. N. H.) 192 Fed. 728; Lyon \& Hoag v. Railroad Comm. (1920) 183 Calif. 145, 190 Pac. 795; Potter Matlock Trust Co. v. Warron County (1919) 182 Ky. 840, 207 S. W. 709; State v. Duluth \& N. M. Ry. (1921) 150 Minn. 30, 184 N. W. 186; Railroad Comm. of Ark. v. Salino River Ry. (1915) 119 Ark. 239, 177 S. W. 897.

11 (1819, U. S.) 4 Wheat. 518.

12 See 2 Willoughby, Constitutional Law (1910) 897 et seq.; 1 Warren, The Supreme Court in United States History (1922) 492.

${ }_{13}$ Bullock v. Railroad Comm. of Fla., supra note 8; Potter Matlook Trust Co. v. Warren County, supra note 10; State v. Duluth \& N. M. Ry., supra note 10 . 
utility for the term specified in the charter. ${ }^{14}$ The exercise of eminent domain or other powers of government which was stressed in the earlier cases does not now serve to fasten any obligation to continue operating the utility upon the owners. ${ }^{15}$ If the utility fails to earn a fair return upon the investment the owner may discontinue service. Why? Because he was not expressly bound by his contract to continue to operate the utility even if it lost money. After reading a large number of cases and noticing that the charters which come before the courts for construction in this class of cases never seem to be mandatory, but always permissive, one wonders whether there is in existence a charter at present which expressly binds the owners of the utility to operate it within the rule laid down by the courts, particularly that expressed by the United States Supreme Court. But suppose that such : charter could be found. By a use of the technique of contract the utility owner would still escape the duty of continuing to operate the plant, because while it is true that property which is utilized in rendering a public service is dedicated to a public use, the consideration for such a dedication is that the public shall use it sufficiently to enable the owner to operate his business as a paying proposition. It is either regarded as a part of the consideration, or a condition on which the dedication is made. ${ }^{10}$ If consideration and conditions present a closed door, the doctrine of lack of mutuality is invoked. ${ }^{17}$ If it be argued that the charter-

14 Railroad Comm. of Texas v. Eastcm Texas R. R., supra note 8; Pcoplo v. Albany \& Vt. Ry., supra note 2; San Antonio St. $R_{y}$. 2. Statc of $T e z a s$ (1897) 90 Tex. 520, 39 S. W. 926.

15 Bullock v. Railroad Comm of Fla., supra note 8; Railroad Comm. of Texas v. Eastern Texas $R$. $R$., supra note 8. But see the opinion in Day $v$. Tacoma Ry. \& Power Co. (1914) 80 Wash. 161, 141 Pac. 347.

18 Railroad Comm. of Texas v. Eastcmi Texas $R$. $R$., supra note 8. In the following cases will be found reference to or discussions of the contractual element under review: State of Tezas v. Eastem Tczas R. $R$. (1922, W. D. Tex.) 283 Fed. 584; Railroad Comm. of Arls. o. Saline River Ry., supra note 10; Potter Matlock Trust Co. v. Warren County, sugro note 10; State v. Eaid O. \& W. Ry. (1917) 108 Tex. 239, 191 S. W. 560; Souticm $R y$. v. Franzilin \& Pittsylzania $R$. $R$. (1899) 96 Va. 693, 32 S. E. 485 . In some cases state aid in money or land grants has been looked upon as placing the grantee under a contractual obligation. See Statc v. Sious City $R y$. (1878) 7 Neb. 357; Farmers Loan \& Trust Co. v. Henning (1878, C. C. D. Kan.) Fed. Cas. No. 4666. In People v. Colorado Ccnt. Ry. (1890, C. C. D. Colo.) 42 Fed. 638 , the court said, "As a general rule, a railroad company accepting a charter from the state, under and in pursuance of which it builds its road, may be compelled to do so if it has received state aid, or if its charter in terms imposes this obligation." The court declined to say what the rule would be in the absence of state aid.

${ }^{17}$ See East Ohio Co. v. Aliron (1909) 81 Ohio St. 33, 90 N. E. 40. It is something of this same notion which prompted the court to say in Bulloci: v. Railroad Comm. of Fla., supra note 8, that the utility must be permitted to abandon without state consent because if it were not it would never be able to abandon service, because the state could not be made a party to 
is granted subject to an exercise of the police power, and that the regulation of public utilities generally is an exercise of the police power, the answer is immediately returned that the United States Supreme Court will determine for itself what are the elements of the charter contract and what particular exercises of the police power is to be deemed reasonable. ${ }^{18}$ Furthermore, if it be thought that existing statutes impose a duty to operate a utility for a charter term (although it is surprising how few statutes there are that cannot be explained out of the contract), ${ }^{10}$ the retort is available that the charter is also issued subject to the Fourteenth Amendment with its tests of reasonableness, and that these would override any existing statutory provisions which would impose a duty to operate the utility at a loss. ${ }^{20}$ Some courts decide the case by saying that a company cannot exercise the privileges of its franchise and at the same time refuse to give service, but that if it cease to render service the charter must be surrendered. ${ }^{21}$ Of course that merely begs the question, for the question to be settled is whether the charter can be surrendered and the duty to continue operation thus be escaped. This type of argument really applies with more propriety to the cases of partial abandonment, and will be touched upon again in connection with cases of partial discontinuance of service.

It must appear quite plainly that if the courts had wished to hold the utility to continued operation in spite of financial loss they might have done so by use of the technique which appears in the withdrawal cases considered in the previous paragraph. What a perfectly familiar line of argument it would have been to have said that a charter is a contract, that the duties imposed by the charter must be fulfilled, and that the police power of the state

a proceeding for permission to discontinue. This argument has apparently met with the fate it deserved, for it has never been referred to in any other opinion or argument which has come to the attention of the writer.

18 Railroad Comm. of Texas $v$. Eastern Texas $R$. $R$., supra noto 8.

19 In addition to the statutes involved in this case see the construction put upon those involved in Jack v. Williams, supra note 10; Central Bank \& Trust Corp. v. Cleveland (1918, C. C. A. 4th) 252 Fed. 530; Stato of Iowa v. Old Colony Trust Co. of Boston, supra note 5.

20 State of Texas v. Eastern Texas Ry., supra note 16.

21 Brooks-Scanlon Co. v. Railroad Comm. of La., supra note 8; Fort Smith Light \& Traction Co. v. Bourland (1925) 267 U. S. 330, 45 Sup. Ct. 249; and see particularly the remarks in Pittsburgh \& Shawmut Coal Co. v. Delaware \& N. R. R. (1923, N. D. N. Y.) 289 Fed. 133. See also Savannah Canal Co. v. Shuman, supra note 1; State ex rel. City of Bridgeton v. The Bridgeton \& Millville Traction Co. (1899) 62 N. J. L. 892, 43 Atl. 715; City of Helena v. Helena Light \& Ry. Co. (1922) 63. Mont. 108, 207 Pac. 337. The California court seems to have held that if a man voluntarily abandons the property he has in a utility plant, leaving it to the public, he thus automatically divests the commission of jurisdiction to compel him to continue operating the plant. See Lyon \& Hoag v, Railroad Comm. of Calif., supra note 10. 
extended to the general power of regulating public utilities and specifically to the regulation of service and the discontinuance thereof; and further, that such limitations on the right to withdraw as the state might see fit to impose were reasonable, and therefore constituted "due process of law". It is submitted that the time has come to abandon the technique of contract in settling public utility questions, at least this sort of public utility question. These charters are not contracts in the private law sense of that term; and the law of contracts generally does not serve any useful purpose in arriving at a proper decision of the question whether the utility should be permitted to discontinue or not. The charter contract theory only takes care of those cases where the utility is owned by a corporation; and it was only due to the fact that so many of the utilities were and are owned by corporations that the courts were led into this technique. It happens to be true that the cases which are appealed to the courts of last resort were usually appealed by corporations. Individual utility owners doubtless were often deterred by the costs involved in time and money from carrying their cases to the courts after commissions have made their findings. There are a number of instances of utilities owned by private individuals. Many of these owners have never received charters nor even franchise grants. But it is not unknown to the law of public utilities to impose upon these owners the burdens and duties of a public calling even though they did not intend to enter that business or lnow that they were doing so. Perhaps they would never have started the business in many instances if they had known the legal situation in which they were placing themselves. It is submitted, however, that the rule on total abandonment is the same whether the owner be a private individual without any charter, or a corporation with either a "permissive" or "mandatory" charter. The reason of the rule and the decisions of the courts seem to warrant the statement that in either of these three instances the decision will be the same, if the owners are able to demonstrate that they are within the class permitted to abandon service entirely because they are losing money on the particular service involved.

What is really involved in these cases of total abandonment is a conflict of economic and social interests. The economic interests of the investor are balanced against those of the consumer, $=$ and the same is true of the attendant social interests. The courts favor the interests of the community in abandonment cases so long as the utility earns a fair return; but when the utility fails to earn a fair return the interests of the owner outweigh those

22 The court in a lower federal case said that the controversy in a withdrawal case was really between the stockholders and bondholders on one side and the people seeking to compel the utility to operate on the other. Central Bank \& Trust Corp. v. Cleveland, supra note 19. 
of the community in the mind of the court. In most of the cases thus far decided involving questions of total abandonment, however, imminent bankruptcy seemed necessary before the courts were willing to shift the scales in favor of the investor. Why should not these factors appear in the opinions rendered by the courts, instead of obscuring the real issues by resorting to the technique of contract? ${ }^{23}$-The charter contract doctrine which, when formulated, allowed public service corporations to retain their franchise privileges, is now being used to free them from the burdens sought to be fastened upon them.

The cases thus far considered have involved the total abandonment of service; but it often happens that a utility wishes to discontinue service on only one portion of its system, because that particular branch is losing money. The rule governing in this type of situation seems to be that loss on a branch, spur, street, or portion of the system will not be sufficient ground for allowing a discontinuance of service on the losing branch. ${ }^{24}$ But if the whole system is so affected by this one branch that the loss on the branch will cause the whole system to lose, it seems that the branch service may be discontinued. ${ }^{25}$ The courts use the technique of contract in many of these cases also; and some of the cases cited

${ }^{23}$ Some writers think that the theory of contract as applied to public utilities generally is giving way to the relational theory which seems to have prevailed at common law. See Albertsworth, From Contract to Status (1923) 8 A. B. A. Jour. 17; Pound, The Spirit of the Common Law (1921) 29.

24 Western \& Atl. R. R. v. Georgia Public Serv. Comm. (1025) 267 U. S. 493, 45 Sup. Ct. 409, Pittsburgh \& Shawmut Coal Co. v. Delaware \& N. R. $R$. supra note 21; Southern Ry. v. Hotcheth (1917) $174 \mathrm{Ky} .463,192$ S. W. 694 (the language of the opinion is unnecessarily broad, but all that is actually decided is the question of partial abandonment); Brovuncll v. Old Colony R. R., supra note 1; Colorado \& So. Ry. v. State R. R. Comm. of Colo. (1912) 54 Colo. 64, 129 Pac. 506; cf. Northerm Illinois $L$. \& T. Co. v. Commerce Cómm. (1922) 302 Ill. 11, 134 N. E. 142. Also Ro Chicago \& N. W. Ry. (1922 A) Pub. Util. Rep. (Wis.) 556; Ro Vulley Railways (1923 A) Pub. Util. Rep. (Pa.) 193. The case of Ro Nowport News \& Hampton Ry. Gas \& Elcc. Co. (1925 A) Pub. Util. Rep. (Va.) 480 , seems to be out of line with the decisions cited above. Tho Virginia commission found in this case that the service furnished by the utility was not earning a fair profit, but nevertheless decreed that because of the inconvenience involved in discontinuing service on certain of the streots served, some of the car service should be maintained. The other services, gas and electricity, were apparently paying services. It was not entirely clear whether the accounts had been kept so as to be possible to tell for a certainty what the earnings of each service were; but from the report of the case it seems that the car service was losing.

${ }^{25}$ State of Iowa v. Old Colony Trust Co. supra note 5. In this case a short branch of an electric railroad on which a steam service was operated was allowed to discontinue because the demand for service was not great, the system as a whole shaky financially, and the roadbed in such shape that to continue operation without considerable repair would be dangerous. 
under the heading of total abandonment in this connection will be found to involve partial abandonment. In these cases the community interest in service on the branch is balanced against the interests of the owners and also those of the other communities who are served by the system as a whole. Here also, as in the cases involving total abandonment, the courts seem to require that there be a real danger of financial ruin by continued branch operation before they will allow the branch to be abandoned. The recent case of Fort Smith Light \& Traction Co. v. Bouriland ${ }^{20}$ does not decide anything contrary to the rules formulated above, although the opinion is not entirely clear. In that case a street railway was trying to escape its franchise duty to pave by abandoning service on the particular street required to be paved. The court decided that the obligation to pave could not be thus avoided, even though it appeared that the company could not afford the outlay of money which would be required by the paving project. The actual decision went no further. The company was earning only $1.7 \%$ on the estimated value of its property; and when the court said that the company could not be forced to continue service if it should surrender its franchise it was doubtless this fact which was in the back of the court's mind. There was a case made out here which would have justified a total discontinuance of service under the rule stated in connection with the cases involving such discontinuance.

The court makes the statement that branch operation may be compelled ". . . even where the system as a whole fails to earn a fair return upon the value of the property." This suggestion is contrary to a decision of one of the lower federal courts, ${ }^{2 \pi}$ and is believed to be contrary to sound policy. It should be the airn of the court to compel the utility to serve as long as that can be done without loss on the whole system, for in that way the entire community will be insured continued service; but when the continuance of the branch at a loss so drains on the whole system as to compel it to cease operation completely, thus resulting in depriving the entire community of service, it seems that discontinuance of the branch should be allowed. The continued operation of as much of the system as can profitably be operated would seem to be a proper goal so long as loss on the whole system means that none of the system need be operated. The court perhaps does not mean exactly what it says, for under the prior decisions of the

${ }^{26}$ Supra note 21. See also Mrilzaulice Elcc. Ry. Co. v. Milurarlice (1920) 252 U. S. 100, 40 Sup. Ct. 306, in which case the road was earnin ses: than six percent but the road was required to pave according to the franchise terms. The court said in the course of its opinion, "The finaneial condition of a public service corporation is a fact properly to be considerel when determining the reasonableness of an order directing an unremunera. tive extension of facilities or forbidding their abandonment."

${ }^{27}$ Supra note 25. 
court the utility could have abandoned service entirely, as previously indicated. If the policy of keeping up the service to the community as long as possible is the desirable one, it seems clear that a losing branch the continuance of which will result in a deficit for the entire system, should be discontinued.

A rate which affords a fair profit for the whole of a street car system is not to be considered as confiscatory, even though some of its lines are losing money. ${ }^{28}$ In illustration of what is meant by the term "system" an interesting Massachusetts case affords an excellent example. In that case a railroad company had taken over the operation of a ferry service and had operated it for some time. It then abandoned this service because it could not be made to pay; but the railroad company was forced to re-open the ferry service on the ground that it had become a part of the system and could not be discontinued as long as the system as a whole was profitable.20 In New York City some thirty ferries were at one time operated by virtue of one franchise; and it was held that where five of these ferries were losing money they must nevertheless be operated, because the thirty considered together were making money for the city. ${ }^{30}$ Where one railroad leases a short line service as a branch, the lessee will not be allowed to discontinue service upon that branch although it is losing money in its operation; and specific performance will lie to compel operation for the term of the lease. ${ }^{31}$ But where the pleadings show that the lease of the road in question was contrary to state law the court will not compel the operation of the leased road. ${ }^{32}$

If the state consents to discontinuance of service on a particular branch, even though the system be a paying business, the service on that branch may, of course, be abandoned. ${ }^{33}$ Some cases asw

${ }^{28}$ Puget Sound Traction, Light and Power Co. v. Reynolds (1916) 244 U. S. 574, 37 Sup. Ct. 705.

${ }^{29}$ Brownell v. Old Colony $R$. $R$., supra note 1.

${ }^{30}$ Matter of Wheeler (1909, Sup. Ct. Spec. T.) 62 Misc. 37, 115 N. Y. Supp. 605. The court decreed that the ferry line in question should bo put up at auction, this apparently being the extent of the city's duty under later legislation. This case is distinguishable from that of Re Bloomington \& Normal R. \& Light Co. (1922 E) Pub. Util. Rep. (Ill.) 770, in that in the latter case the utility was furnishing two types of service, steam and hot-water heat; but when the commission allowed the discontinuance of ono of the services the customers still had an adequate heating service left. In the case of the ferries, however, it was apparently shown to the court that many people would be without any adequate transportation service if the ferries were discontinued.

${ }^{31}$ Southern $R y$. v. Franklin \& Pittsylvania $R$. R., supra note 16.

32 People v. Colorado Cent. Ry., supra note 1.

${ }^{33}$ See, however, Pittsburgh \& Shawmut Coal Co. v. Delawaro \& $N$. $R$. $R$., supra note 21 , where the court refused to allow a receiver of a road to discontinue a losing branch without the consent of the state, this being the rule of the state decisions. See also Southern Ry. v. Hachett, supra note 24; New York Trust Co. v. Buffalo \& Lake Erie Traction Co. (1920, 
sert that the charter of a corporation which has discontinued service on a losing branch without state consent is subject to forfeiture upon the bringing of a proper action. ${ }^{84}$

There is some diversity of opinion on the question whether the utility should be compelled to re-arrange its routings with a view to making up the deficit on a particular line, by diverting traffic from other profitable lines over the losing line. It appeared in one case that the deficit could be made up by such a re-routing of the traffic, but the commission refused to consider this phase of the case and granted a petition for discontinuance on the losing line. ${ }^{35}$ In another case, however, it was said that the company was bound to abandon every losing line in order to preserve the main lines, and that the utility would be beld to every economy before it would be permitted to discontinue service. ${ }^{36}$

It is to be remembered that it is a service which is to be abandoned, and that it makes no difference so far as the rules regarding discontinuance and dismantling are concerned, whether the owner be an individual, a corporation, or a municipality. ${ }^{3 r}$ The person or corporation may not be the one which founded the business in a given instance and may have purchased the physical

Sup. Ct.) 112 Misc. 414, 183 N. Y. Supp. 278; City of Helcna v. Helcnes Light \& Ry. Co., supra note 21.

34 See People v. Albany \& Vt. Ry., supra note 2; Stato cr rel. City of Bridgeton v. Bridgeton \& Millville Traction Co., supra note 21; Railroud Comm. of Ark. v. Saline River Ry., supra note 10; San Antonio St. Ry. $v$. State of Texas, supra note 14 . In this case the court did not appear to make any distinction between total and partial abandonment of cervice, but held that mandamus would not issue to compel service on a certain street, because the franchise was construed to be only permissive and not mandatory. This case is to be closely confined to its facts, and really decides nothing more than that the charter is not mandatory. In Attomey Gen. v. The West Wis. Ry., supra note 2, the court declared that action would lie to forfeit the charter for having changed the terminals specificd in the charter granted the owners of the road. Statc $\%$. Sious City $R y$, supra note 16, is a case of restricted authority. Action was brought to quiet title to land donated by the state to the road; and the action has been brought by the state before the period for fulfilling the conditions of the grant had expired. The company was solvent, however, and the court did intimate that mandamus would issue in a proper action to compel operation according to charter terms.

${ }^{35}$ Re Beaver Valley Traction Co. (1924 A) Pub. Util. Rep. (Pa.) 444.

${ }^{36} \operatorname{Re}$ Boston and Iraine Ry. (1925 A) Pub. Util. Rep. (N. H.) 133. See also in this connection Re Oronogo Gas Co. (1924 C) Pub. Util. Rep. (MIo.) 373. This case involved a question of total abandonment; and the Miscouri commission held that if the loss was attributable to faulty management by the company, a petition to discontinue would be disallowed.

${ }^{37}$ For a case involving a municipality see Fellows v. Los Angelcs, sugro note 9. 
plant at a judicial sale,$^{38}$ or may even be a lessee of the utility..$^{30}$ In all events he or it is subjected to the same duties as were imposed upon the original owner, at least as far as withdrawal is concerned, it being assumed that the succession to the plant has been by methods recognized by the law in this class of cases.

The cases involving total abandonment of service may include utilities rendering a single service, or one rendering several distinct and separate services, such as heat, light, transportation. and telephone service. No distinction has been drawn in most of the commission cases between the abandonment of a single service utility or the abandonment of one entire service of several being rendered. ${ }^{40}$ To illustrate, where a company was rendering gas, electric, and steam-heat service and wished to abandon the steam-heat service because that service was losing money, the company was permitted to discontinue the service under the same rule which governs total abandonment of a single service utility.41 If a telephone company has voluntarily entered the express business and wishes to discontinue the express business because it is not desirable to continue it, although the express business is a profitable one, still the telephone company must continue to operate that business in connection with the telephone business. ${ }^{42} \mathrm{But}$

${ }^{38}$ State $v$. Beaton, supra note 5 , is an example of a judicial sale purchaser. See also Re Kaneville Grain and Supply Co. (1923 E) Pub. Util. Rep. (Ill.) 167; Commonwealth of Va. ex rel. Va. Table Co. v. Irnight (1923 E) Pub. Util. Rep. (Va.) 816; Cripple Creel Motor \& Commeraial Club v. Colorado Springs \& Cripple Creek Dist. Ry. (1924 A) Pub. Util. Rep. (Colo.) 392. See for the effect of a state statute requiring purchasors at judicial sale to operate the road, Railroad Comm. of Texas v. Eastern Texas Ry., supra note 8; State v. Dodge City \& Trinidad Ry. (1894) 53 Kan. 377, 36 Pac. 747; City of Potwin Place v. Topeka Ry. (1893) $51 \mathrm{Kan}$. 609, 33 Pac. 309. Receivers appointed by federal courts are also subject to the same duties as owners in abandonment matters. Pittsburgh \& Shawmut Coal Co. v. Delaware \& N. R. Co., supra note 21.

${ }^{30}$ Southern Ry. v. Franklin \& Pittsylvania R. R., supra note 16.

${ }^{40}$ Re St. Croix Gaslight Co. (1919 A) Pub. Util. Rep. (Me.) 487; Ro Winona Electric Light \& Water Co. (1920 F) Pub. Util. Rep. (Ind.) 968; Board of Trustees of Waterville v. Waterville Gas \& Elect. Co. (1917 F) Pub. Util. Rep. (N. Y.) 126. In the case of In Re Newport News \& Hampton Ry. Gas \& Elec. Co. (1925 A) Pub. Util. Rep. (Va.) 480, the Virginia commission seems to have acted contrary to the view stated above. In that case the car lines were losing, and the other services were paying; but the discontinuance of service was allowed only on some of the car lines. In City of Spartanburg v. South Carolina Gas \& Light Co. (1924, S. C.) $125 \mathrm{~S}$. E. 295, the court refused to allow the discontinuance of car service although that service was losing money, because the franchise was construed to bind the company to operate the gas and light services with the third service. It was held that all must be operated or none, but turning as it does on the construction of the franchise, the case is not in conflict with the rule stated above.

${ }^{41}$ Board of Trustees of Waterville v. Waterville Gas \& Elec. Co., supra note 40.

42 In Re Butters' Express (1921 B) Pub. Util. Rep. (Mass.) 452. 
if one of two services is losing while the other service pays very well, the losing service will be permitted to discontinue. ${ }^{33}$ This is the more true where the two services are of similar natures, such as, for example, two types of heating service, it appearing that the public can be taken care of adequately by the remaining heatiit: service. $^{44}$ It should be added that these commission cases have the support of at least a strong judicial dictum, if not an actual decision. ${ }^{25}$ This raises a problem in accounting also, for it sometimes happens that some of the same physical plant is used for the several separate services, and it is not always easy to tell what the allocation of costs of services should be.43 Commissions are perhaps in a better position than the courts to work out such a body of rules as may prove to be necessary to take care of these situations. The treatment of each service separately, standing on its own feet, would seem to be proper; for the people using gas but not heat should not be made to bear a share of a losing heating service deficit. To continue operating the losing service may burden the other services to the extent of maling it necessary to abandon them all. It would seem that the aim in all these cases should be to preserve as much of the service to the public as is possible. When this test is applied to the rule formulated by the commissions in the above cases the decisions seem sound.

There are numerous illustrations of public utility service rendered by individuals or corporations engaged primarily in a nonutility business. These are to be treated the same as though their only business was that of a public utility; and if the utility service is losing, the other types of business in which the company may be engaged can not be made to bear the burden of the losing service.:

13 Re St. Crois Gaslight Co., supra note 40.

44 Re Bloomington \& Normal R. \& Lt. Co. (1922 E) Pub. Util. Rep. (Ill.) 770. See People v. Rome W. \& O. Ry. (1886) 103 N. Y. 95,8 N. E. 364 , where one road consolidated with another, both roads having the same terminals, and mandamus to compel operation of the one line which had been discontinued was denied. In Day $v$. Tacoma $K_{y}$, supra note 15, one street car line had been rendered profitless by the building of a parellel line; and the owner was allowed to discontinue the losing line because the abandonment was said not to work "a prejudice to the public interest." There being adequate service still remaining, the case was said not to be within the general rule referred to above, the court saying that it would not lend its aid to compel competitive service.

${ }_{45}$ Northern Illinois L. \& T. Co. v. Commeree Comm., supra note $\mathbf{2 1 .}$

${ }^{40}$ On this problem see $R e$ Alton Gas \& Elcetric Co. (1917 F) Pub. Util. Rep. (IIl.) 12.

47 For illustrations of lumber or logging companies establishing railroads see Broolss-Scanlon Co. v. Railroad Comm. of La., supra note 8; Bullocl: v. Railroad Comm. of Fla., supra note 8; Railroad Conm. v. Saline Kivcr Ry., supra note 10. Mrontell v. Consolidation Coal Co. (1876) 45 IId. 16, was a case of a road built by a coal company; but since the holding out had perhaps not been general, the road was allowed to be withdrawn. The following cases involved furnishing of lighting service, Re Rcd Ricer Xffg. 
One of the most important of the problems raised by recent withdrawal cases is that of the substitution of service. Due to the growth of auto bus competition with street car and other suburban lines, this question of substitution of service has become very acute in some localities. ${ }^{48}$ It may well be that the only method whereby the street car company can escape financial ruin because of these competing transportation services is that of establishing a bus service itself. There would seem to be no reason from the point of view of the public why this should not be allowed in such a case. But in a South Carolina case where the question was squarely raised, the charter of the company was construed to obligate it to furnish car service and car service only; and the court insisted that the charter was a contract, the terms of which must be fulfilled.90 As a result a commission order allowing the substitution of the bus service was set aside. This would seem to illustrate from another angle the objection to using the technique of contract in public utility cases. The courts have held, quite correctly it is believed, that they will not aid in compelling competing services to be furnished the public when it appears that the public is being adequately served by the remaining utility. ${ }^{50}$

Thus far we have been examining the situations in which the right exists to withdraw from service totally or partially. The state may not compel the utility to operate in certain cases, but it may take precautionary measures to make certain that the utility in any given case is within the class entitled to withdraw. The commission may therefore require the filing of a petition for leave to discontinue; and to require such a petition and continued operntion while action thereon is pending does not conflict with the "due process" clause of the Fourteenth Amendment."1 A utility may not discontinue service arbitrarily merely because it is being unfairly, or even illegally, treated by a municipality, but must seek

Co. (1924 D) Pub. Util. Rep. (Wis.) 385 (lumber co.); Re Gilmanton Roller Mills Co. (1921 B) Pub. Util. Rep. (Miss.) 815 (roller mills); Ro Van Auken Pub. Utilities Plant (1925 A) Pub. Util. Rep. (N. H.) 460 (gàrage); Dunwell v. Fried Co. (1924 A) Pub. Util. Rep. (N. D.) 607 (hardware).

${ }^{48}$ See the discussion in Re Valley Railways, supra note 24.

${ }^{49}$ City of Spartanburg v. South Carolina Gas and Light Co., supra note 40; see also supra note 40 .

50 See cases supra note 44.

51 Western \& Atl. R. R. v. Georgia Public Service Comm., supra note 24; State ex rel. Caster v. Kansas, Postal Tel.-Cable Co. (1915) 96 Kan. 298. 150 Pac. 544; State v. Missouri Southern Ry. (1919) 279 Mo. 455, 214 S. W. 381; Herpolsheimer Co. v. Lincoln Traction Co., supra note 4; Peoplo ex rel. Hubbard v. Colorado Title \& Trust Co., supra note 4. See also People's National Gas Co. v. Public Serv. Comm. (1924) 279 Pa. 252, 123 Atl. 799. Also the list of cases in Dunwell v. Fried Co., supra note 47, at 514. 
redress for wrongs done it through the legal channels afforded; and while such relief is being sought service must continue to be furnished. ${ }^{52}$ But a grant of power to a commission to refuse permission for discontinuance if the commission finds that such withdrawal would prejudice the public interest is perhaps unconstitutional.53 A utility which is unable to continue operation because of inability to renew an essential contract, partly as a result of a previous judicial decision, cannot be compelled by a cornmission to carry on operations. ${ }^{54}$ The commission may find that the utility should not be permitted to withdraw; and in such a case resort may be had to the courts on the questions of law which may be involved. On the other hand, the commission may grant permission to withdraw even though the city served by the utility is a party to the alleged contract.5

A state commission may be authorized to supervise receivers of public utilities; $;^{50}$ and the receivers appointed by federal courts are apparently in the same position as receivers appointed by state courts so far as withdrawal matters are concerned.5: Purchasers at a judicial sale held under authority of a federal court should also be in a similar position; and one commission has so decided."s The Interstate Commerce Commission has been empowered to permit withdrawal from service by interstate carriers; but this does not extend to intrastate utilities..$^{.3}$

52 City of Gainsville v. Gainsville Gas and Elec. Co. (1913) 65 Fla. 401, 62 So. 919.

53 State v. Duluth \& N. MI. Ry., supra note 10; see also (1921) G Mrsis. L. REV. 81.

54 State v. Western Union Tel. Co. (1922) 208 Ala. 22S, 94 So. 466. In this case the contract which the telegraph company had to place its poles on the right of way of a railroad had expired, and the court held that this amounted to an involuntary abandonment.

55 City of Spartanburg v. South Carolina Gas and Light Co., supro note 40. It was held in this case that the city could not tie the hands of the state in its exercise of the police power under the Missouri constitution.

"5 People es rel. Hubbard v. Colorado Title $\mathcal{E}$ Trust Co., supro note 4.

57 See Pittsburgh \& Shawmut Coal Co. v. Delaware \& N. R. R., mipra note 21, referring to section 65 of the Judicial Code.

ss Cripple Creel IIotor \& Commercial Clubb v. Colorado Springs \& Cripple Creek Ry., supra note 38.

"9 State of Texas v. Eastem Teras $R$ y. (1922) 258 U. S. 204, 42 Sup. Ct. 281, construing sec. 402, pars. 18-20 of the Transportation Act of 1920 . The court said that if the paragraphs here considered extended to intrastate commerce they would be unconstitutional, but construed them to refer only to interstate commerce. The court has said that a mere relocation of the main track of an interstate carrier, not involving an abandonment of main tracks or substantial change of destination does not fall within the paragraphs referred to above. Railueay Comm. of Calif. v. Southcm Pac. Co., (1924) 264 U. S. 331, 44 Sup. Ct. 376 (holding that a state could not compel interstate carriers to build a new union station where a number of existing stations would thereby have to be abandoned, and the lines leading to the station changed). The sections of the Transportation Act re- 
The rule seems well established by recent adjudications of the United States Supreme Court that a public utility which is losing money may under certain circumstances not only discontinue service but may also dismantle its physical plant and sell the same as salvage if it wishes to do so. ${ }^{60}$ There were previous cases in the lower federal courts and in some of the state courts which had indicated that this would be the rule; and attempts by public authorities to enjoin the owners of the utility from removing their physical equipment had failed in several instances. ${ }^{61}$

But a utility is not allowed either to discontinue service or to junk its plant whenever and however it sees fit. With the advent of commission regulation this phase of withdrawal cases received attention. Commissions have been given jurisdiction over the dismantling of plants in some states, and a petition is required to dismantle, as it is to discontinue service. ${ }^{62}$ In the days prior to commission regulation the public was dependent upon the alertness of the legal representative of the state or local governmental

ferred to do not apply to spur tracks. See sec. 22 , and Westerm \& Atl. R. R. v. Georgia Public Serv. Comm., supra note 24.

${ }^{\circ 0}$ Railroad Comm. of Texas v. Eastern Texas $R$. R., supra note 8. Tho court stated in this case that the denial of the right to salvage value is contrary to the "due process" clause of the Fourteenth Amendment. Tho opinion explicitly asserts that the withdrawing utility may "get what it can out of the property by dismantling the road." The earlier cases of Bullock v. Railroad Comm. of Fla., supra note 8, and Broolss-Scanlon Co. v. Railroad Comm. of La., supra note 8, did not expressly decide this point, although on the facts of those cases they might have been interpreted to extend this far.

o1 Jack v. Williams, supra note 10, aff'd (1906, C. C. A. 4th) 145 Fed. 281. Also Laighton v. Carthage (1909, C. C. D. Mo.) 175 Fed. 145, whero a water company was allowed to go into streets to pull up mains and hydrants. The court said in the course of its opinion, "The right of complainant at the termination of the contract to enter upon the streets of the city to remove its plant, without let or hindrance, does not admit of debate." See New Yorle Trust Co. v. Portsmouth \& Exeter Strect Ry., supra note 10; Gilchrist $v$. Waycross St. \& Suburban Ry. (1917, S. D. Ga.) 246 Fed. 952; State of Texas v. Eastern Texas Ry., supra noto 16; Pottor Matlock Trust Co. v. Warren Co., supra note 10; East Ohio Gas Co. v. Akron, supra note 17; Enid O. \& W. Ry. v. State (1915, Tex. Civ. App.) 181 S. W. $498, r e v^{\prime} d$ in (1917) 108 Tex. 239, 191 S. W. 560. In Railroal Comm. v. Saline River Ry., supra note 10, the court said that the fact that discontinuance of service was permitted did not necessarily mean that tho utility might tear up the tracks. See Notes (1919) 32 Harv. L. Rev. 716, and CoMments (1922) 32 YALE LAW JournaL, 75, wherein the writers incline to favor restricting the privilege to dismantle.

on People ex rel. Hubbard v. Colorado Title \& Trust Co., supra note 4; Cripple Creek Motor \& Commercial Club v. Colorado Springs \& Cripplo Creek Dist. Ry., supra note 38; Re Kaneville Grain \& Supply Co., supra note 38. The reasoning of Western \& Atl. R. R. v. Georgia Publio Servico Comm., supra note 24, sustaining a commission rule requiring a petition to the commission before service be discontinued, would doubtless apply to $\mathfrak{a}$ similar rule regarding dismantling the plant. 
unit; and the remedies of injunction and mandamus were resorted to ${ }^{63}$ although specific performance was not considered a proper mode of relief..$^{-4}$ If the utility had actually dismantled a portion of the plant the courts did not usually compel the utility to restore the plant and resume operation. ${ }^{65}$ It seems, however, that the English courts have done this, ${ }^{\mathrm{C}}$ and that one or two American courts have also applied a similar doctrine.6:

The courts and commissions have evolved several administrative rules which are usually designed to make certain that the utility which is to withdraw from service and sell or dismantle its plant shall do so in a manner that will work the least hardship upon the public.

The courts have sometimes ordered receivers of bankrupt utilities to operate the utility for a test period if there is any doubt about the ability of the utility to earn a return sufficient to warrant keeping it in the public service. ${ }^{\text {ss }}$ And receiver's certificates may be issued in the discretion of the court during such a test period, though the court is likely to be inclined to exercise this power rather cautiously. ${ }^{69}$ If such a test period proves conclusively that the utility is a losing venture beyond any reasonable hope of restoration, the court will often entertain some sort of proposal whereby the community affected may post a guarantee to take care of the deficit which is likely to be incurred by a con-

${ }^{63}$ People v. Albany \& Vt. R. R., supra note 2; Attomcy Gcr. a. The West Wis. Ry., supra note 1. See also Brounzell v. Old Colonz $R$. $R$., supro note 1 .

64 People v. Albany \& Vt. R. R., supra note 2.

65 Jack v. Williams, supra note 10; Lyon and Hoag 2. Railrogd Comm. of Calif., supra note 10; People v. Albany \& Vt. $R$. R., supra note 61.

co Rex v. Severm \& W. R. R. Co. (1819, K. B.) 2 Barn. \& Ald. 610.

Ga Brownell v. Old Colony $R$. $R$., supra note 1, where a ferry was abandoned for twenty years, but ordered to be re-opened. See Attomcy Gcn. 2 . The West Wis. Ry., supra note 1. And in Saramah Canal Co. a. Sluman, supra note 1 , the court ordered service to be given, but said that it would consider the fact that the company could not raise funds (if sueh were shown to be the case) as tempering its judgment in any conterupt proceeding which might follow the decree.

6s This had apparently been the case in the earlier stages of the proceedings in Bullock v. Railroad Comm. of Fla., supra note 8. Sce also the statement of facts in Enid $0 . \&$. F. $R y$. 2 . Statc, supra note $61 ;$ Nav Forl: Trust Co. v. Buffalo \& Lake Erie Traction Co., supra note 33. In Pittsburgh \& Shawmut Coal Co. v. Delazede of N. R. R., supro note 21, the receiver had operated the road two years and was making the venture pay. He was not allowed to discontinue a losing branch which he had petitioned the court for leave to abandon. In Potter Matlocl: Trust Co. v. Warren County, supra note 10, if the road could not be sold as a going concern a receiver was to run it for one year before selling it as serap.

69 Central Bank aind Trust Corp. 2. Clevcland, supra note 19; Gilelirist v. Waycross St. \& Suburban $R_{y}$. (1917, S. D. Ga.) 246 Fed. 952; Gasoer v. Garden Bay Ry. (1919) 205 Mich. 5, 171 N. W. 791. 
tinued operation of the plant.. ${ }^{\circ}$ Of course such guarantees must be substantial, and of such a nature that the owners of the utility will not have their interests jeopardized by the arrangement."1

Commissions will usually try the expedient of higher rates before they will permit the owners to discontinue service. But if the rates have reached the point where the traffic falls off because of them, and the utility is continuing to lose money, the commission will decree a sale or dismantlement of the plant. ${ }^{72}$ This accomplishes much the same result as that attained by the courts in the procedure outlined in the previous paragraph.

When test periods, higher rates and guarantees have failed, courts and commissions still attempt to safeguard the interests of the patrons by ordering that the utility be offered for sale as a going concern, to some individual or group of individuals who will continue to operate the plant. ${ }^{73}$ If within a fixed period ${ }^{74}$ no purchaser who will promise to operate the plant has appeared, the courts still are usually willing to give the public an opportunity to buy the utility, either through a citizens' organization or through the local governmental authorities..$^{\pi 5}$ Not until it appears that it is improbable that the utility can be sold as a going concern will the courts or commissions decree the dismantling of the plant and the sale of the equipment as junk. Some courts have been more lenient than others in these matters, and a few have said that the plant is to be sold in that manner which will bring the largest return to the creditors. ${ }^{76}$ Occasionally a court seems

${ }^{70}$ Central Bank and Trust Corp. v. Cleveland, supra note 19; Ro Boiso Valley Traction Co. (1920 F) Pub. Util. Rep. (Idaho) 962; Re St. Croix Gaslight Co., supra note 40; See also Notes (1919) 32 HARv. L. REv. 716.

${ }^{71}$ Re St. Croix Gaslight Co., supra note 40.

${ }^{2}$ Re Boise Valley Traction Co., supra note 70; Re St. Croix Gaslight Co., supra note 40; Re Red River Mfg. Co., supra note 47.

73 In the following cases the courts or commissions ordered the plant to be sold as a going concern: New York Trust Co. v. Portsmouth \& Exotor Street $R y$. (1911, C. C. D. N. H.) 192 Fed. 728; Potter Matlock Trust Co. v. Warren Co., supra note 10; Gress v. Village of Ft. Loramio (1919) 100 Ohio St. 35, 125 N. E. 112; Re Van Auken Public Utility Plant (1925 A) Pub. Util. Rep. (N. H.) 460. Re Red River Mfg. Co., supra note 47; Re Boise Valley Traction Co., supra note 70. In Comments (1922) 32 YALE LAW JOURNAL, 75, a note writer says, "While an unprofitable utility may be permitted to cease its operations, yet the public interest still continues in it to the extent that the company shall not be allowed to stand in the way of another company seeking to render such service."

74 See cases supra note 73.

75 See particularly the opinion in Gasser v. Garden Bay $R y$. (1919) 205 Mich. 5, 171 N. W. 791. Also Re Richfield Public Service Co. (1922 A) Pub. Util. Rep. (Idaho) 100. See the suggestion to this effect in Re Red River Mfg. Co., supra note 47.

76 In New York Trust Co. v. Buffalo \& Lake Erie T. Co., supra note 33, the court withheld an order to dismantle the road because there was somo conflict of opinion as to whether the road would bring more as a going 
to lose sight of the fact that the public is interested in the disposition of a public utility plant, a recent Illinois case aftording an excellent example. ${ }^{\pi 7}$ In this case the court decreed the sale of a bankrupt road in such parcels that it was virtually impossible for the road to be continued in operation. The case is opposed to the prevailing practice among state and federal courts, which is to decree the sale in foreclosure proceedings of a railroad so that the system may be continued in operation as a system, or else to sell it in parcels capable of being operated separately wherever that is possible. ${ }^{\text {is }}$

The public is given a reasonably adequate time in which to adjust itself to the new situation; and the utility is quite generally required to give notice to the public that the service is to be discontinued..$^{73}$ The length of such notice depends upon the circum-

concern or as junk. See also Gilchrist v. Waycross St. \& Sub. Ru., supro note 69 .

iT Equitable Trust Co. of N. Y. \%. Clicago P. \& St. L. Ry. ct al. (Brundage, Atty. Gen., Intervenor) (1924) 314 IIl. 90, 145 N. E. 290. Sec the adverse comment on this case in (1925) 31 YALE LAW JounNar, 561. There was a dissenting opinion in the case. The court explained its attitude when it said, "There was no issue in which the state was concerned." The suggestion which was made by the court that the state could sue later if the buyers did not operate the road must not be taken seriousls, because it was evident that this would be a practical impossibility.

is That this is the rule observed, see Low v. Blacliford (1898, C. C. A. 4th) 87 Fed. 392; Peoria \& Springfield R. R. v. Thompson (1832) $103 \mathrm{Il}$. 187, where it was said, "In view of the public character of the road, it will not be questioned that the public generally have a direct interest in lieeping it continuously open . . . to meet all the legitimate wants of the public." The court further payed its respects to the sort of action talien by the Illinois court in the case eited in the text by saying, "Morcover, it is difficult for us to believe that the wrecking of the property of a railroad company, and selling it out by piecemeal, would in any case be for the best interests of the public or those having an interest in its assets." See also Dayton, Xenia \& Belpre R. R. v. Lewton (1870) 20 Ohio St. 401. In Metropolitan Trust Co. of N. Y. v. Chicago, \& E. I. $R_{y}$. (1918, C. C. A. 7th) 253 Fed. 868, the road was sold in parcels, but each parcel could be operated as a complete road in itself.

39 The following cases illustrate the requirement of notice, $\mathrm{Ncw} Y \mathrm{Yorl}$ Trust Co. v. Buffalo etc. Ry., supra note 76 (3 months); Re MIuss. N. E. St. $R y$. (1924 A) Pub. Util. Rep. (N. H.) 700 (30 days); Re Riolficld Public Service Co., supra note 75 (3 months); Re Tan Aukm Public Utility Plant, supra note 73 (30 days); Re Molelumze River Pouver \& Water Co. (1924 E) Pub. Util. Rep. (Calif.) 557 (reasonable time to let citizens make other arrangements). In Southem Bcll Tcl. \& Tel. Co. v. Railroad Commt. of S. C. (1922, E. D. S. C.) 280 Fed. 901, at 906, the court said that a public utility corporation exercising its right to cease carrying on business because of financial loss, " . . . might be restrained from doing so for such a reasonable tine as would permit the state to meet the situation and endeavor to provide for the service of the public." For an Ohio statute requiring four weeks' published notice zee Village of St. Clairsville v. Public Util. Comm. (1921) 102 Ohio St. 674, 132 N. E. 151. See Va. Rev. Sts., 1923, sec. 4379. See Anonymons caso, (1623, K. B.) 
stances of each case; and it has been held that a utility furnishing a seasonal service, such as heat, may not discontinue service even though losing money, upon such a short notice that the community would be left without adequate heating service and would be unable to provide themselves with one before cold weather. ${ }^{\text {so }}$

Sometimes public utility corporations have attempted to escape the burdens imposed upon them by effecting a dissolution of the corporation. In many states there is no special statutory provision for the dissolution of public utility corporations; and the question has been raised whether the statutory provisions which govern the dissolution of private corporations generally are applicable. Courts have differed in their interpretation of such phrases as "every corporation" or "any corporation". The Virginia court decided in the case of Jeffiries $v$. Commonwealth ${ }^{s 1}$ that a public utility corporation might dissolve itself in the manner provided for by a general provision in a statute to the effect that "Every corporation of this state shall have power . . . to wind up and dissolve itself." The Corporation Commission was denied the power to refuse the consent of the state in such dissolution proceedings, and the state constitution was construed to have given such consent beyond legislative recall. ${ }^{82}$ In Arkansas an almost identical statutory provision as that under review in the Virginia case was construed not to be applicable to public service corporations..$^{83}$

Where there is no special statutory provision for the dissolution of public service corporations, and the corporation dissolves itself in accordance with the general provision on the dissolution of corporations, without the consent of the state, it has been held that a minority stockholder may not object to dissolution on the ground that the consent of the state has not been given. ${ }^{84}$ It has

Goodbolt, 345 reprinted in Burdick, Cases on the Law of Public Servicc (1916) 445.

${ }^{80}$ Re Winona Electric Light \& Water Co. (1920 F.) Pub. Util. Rep. (Ind.) 968.

81 (1917) 121 Va. 425,93 S. E. 701.

82 Sec. 154 of the Virginia Constitution of 1902 provides, "Provision shall be made, by general law, for the voluntary surrender of its charter by any corporation, and for the forfeiture thereof for non-user or mis-user." In sec. 3810 of Gen. Sts. of Va., 1923, a published notice for each of four weeks by a public service corporation is required prior to proceedings of dissolution; and it seems that the commission is empowered to deny such dissolution if after an investigation it sees fit to do so. Whether the Virginia court will declare this portion of the section contrary to the state constitutional provision quoted above is problematical, although in the Jeff rics case the court did stress the constitutional provision. See note to sec. 3810 , in which the unsatisfactory state of the law under this decision and the section enacted to remedy it is discussed at some length by the annotator. 281.

${ }^{83}$ Freeo Valley Railroad Co. v. Hodges (1912) 105 Ark. 314, 151 S. W.

${ }^{84}$ Moore v. Lewisburg \& R. E. Ry. (1917) 80 W. Va. 653, 93 S. E. 762. 
also been decided that a charter may not be surrendered by the president and directors of a public service corporation, but that appropriate action must be taken by a majority of the stockholders. ${ }^{85}$

In Massachusetts a statute forbade gas companies to transfer their franchises, lease their works, etc. without legislative consent. An attempt was made by one utility corporation, through the method of reorganization, to effect without legislative consent what the court believed to be substantially such a transfer as the statute forbade. In the course of its opinion the court said, ${ }^{r}$ ". . . it cannot surrender its franchises nor disable itself from the performance of its public functions without the consent of the legislature."

While this might seem at first glance to be a decision of somewhat doubtful soundness in the face of some recent federal decisions noted previously, still it may perhaps be sustained upon the general power which legislatures have over matters of incorporation, transfer of franchises, and similar matters falling under the police power of the state.

A corporation which was not originally organized for the purpose of engaging in public service, but which was declared to be within the jurisdiction of the public service commission of a state because the corporation in question owned a controlling block of stock in a public utility corporation, was allowed to withdraw from commission jurisdiction by transferring this stock to private individuals.si The dissolution of this relationship was held sufficient to restore the corporation to the status of an ordinary private corporation. The court seemed to stress the fact in this case that the holding corporation did not serve the public directly in any way.

No case has been found in which the owner of the utility was seeking to abandon the service and dismantle the plant where he was earning what the courts would call a fair return but which to him was not satisfactory. Whether an investor in a public

This court also construed the general corporation provision governing dissolution to apply to public service corporations and is therefore in aceord with the Jeffries case on this point.

${ }^{85}$ Town of Gassaway v. Gassaway Gas Co. (1914) 75 W. Va. 60, 83 S. E. 189.

s6 Attomey Gen. v. Haverhill Gaslight Co. (1913) 215 Mass. 394, 400, 101 N. E. 1061, 1064. See also Cumberland Tel. \& Tel. Co. v. Evantarille (1903, C. C. D. Ind.) 127 Fed. 187, at 191, where the court said in the course of its opinion, "A quasi-public corporation cannot disable itcelf for the performance of its functions by the sale and transfer of all its property without legislative authority." The court found no statutory authorization for the transfer in this case.

si Southem Ohio Power Co. v. Public Utilitics Comm. of Olio (1924) 110 Ohio St. 246, 143 N. E. 700. 
utility will be compelled to keep his money there when he wishes to take it out and invest it in some more profitable business is a problem which the courts may be called upon to answer in the not distant future. Lest such a suggestion be thought too academic, attention is called to a case where the owners of the utility felt that they would profit by selling the plant as junk, due to the prevailing high price which would be paid for some of the materials which would be disposed of in that way. ${ }^{8 s}$

An attempt has been made to state as accurately as the writer has been able the rules thus far laid down by the courts in handling withdrawal cases. Many problems have been suggested which will remain to be answered in the future. The type of answer to be given may be different from that which might be given if the problem were to be settled today, because of the changing economic and social ideas which are important factors in cases like those considered in this paper. One can not but wonder, however, what the Interstate Commerce Commission would do if one of the transcontinental carriers should come to it seeking permission to discontinue its entire service, all saving possibility of rates and regional pools having failed to make the road pay. The question seems naturally to present itself at the conclusion of a study of the cases on withdrawal whether regulation by the government of privately owned utilities of such magnitude is only transitory, and the end either unrestricted private control or government ownership.

${ }_{88}^{8}$ Moore v. Lewisburg \& R. E. Ry., supra note 84. 